\title{
POLITICAL AND SOCIAL APPLICATIONS OF EUROPEAN PHYSICIANS IN NASSERI PERIOD OF QAJAR COURT
}

\section{Mohammad- Ali Parghoo ${ }^{1}$ - Ghaffar Abdollahi Matanaq ${ }^{2}$}

\begin{abstract}
Öz
Avrupalı Hekimlerin Nasır Döneminde Kacar Sarayı'ndaki Politik ve Sosyal Uygulamaları Safevi döneminden itibaren Avrupalıların ve yabancıların İran sarayına girmeleri sonraki dönemlerde de devam etti. Rus-İran Savaşı ve Abbas Mirza'nın reformlarının ardından İran'daki Avrupalı varlığı arttı ve çeşitli kişiler eğitim, askerlik, ekonomi ve tıp gibi farklı alanlarda görevlendirildiler. İran'da bulunan Avrupalılar arasında hekimler özel bir konuma sahiptiler. Muhammed Şah Kacar döneminden itibaren saray hekimi Avrupalılar arasından seçiliyordu. Avrupalı hekimlerin nüfuzu Nasır ed-Din'in uzun hakimiyetinde arttı. Bu dönemde çok saygın bir konuma ulaşan şahın özel hekimine sıkça şah ve saray mensupları tarafından danışılıyordu. Avrupalı hekimlerin Nasır'ın sarayındaki sosyal ve politik etkilerinin artmasıyla Avrupa ülkeleri şahın özel hekiminin kendi uluslarından seçilmesi için çabaladılar. Böylece Avrupalı hekimlerin uygulamaları mesleki ve bilimsel konuların ötesine geçip politik bir mesele haline gelerek Avrupalı bakanlar ile İngiliz ve Fransız elçilerinin gündeminde yer aldı. Bu makalede Nasır döneminde Avrupalı hekimlerin politik ve sosyal uygulamaları ve onların İran'ın Avrupa'nın büyük güçleri ile olan politik ilişkilerindeki rolü ele alınmıştır.
\end{abstract}

Anahtar Kelimeler: İran, Avrupa Ülkeleri, Şah'ın Özel Hekimi, Siyasal Denklemler.

\begin{abstract}
The penetration of European and foreigners' to the Iranian court which had started from Safavid continued also in the following periods. After the Russo- Iranian war and the reforms of Abbas Mirza, the presence of Europeans in Iran increased and various people in different duties like education, military tasks, economy and medicine were recruited. Among the Europeans who were in Iran, the physicians had the special status. From Mohammad Shah Qajar era, court physician were selected from Europeans. The penetration of European physicians increased in Nasser alDin's long reign. In this period, the shah's private physician had the best position and usually was consulted by shah and courtiers. By increasing the European physicians' social and political influence in Nasseri court, European countries tried to select the shah's private physician from their nationals. So, the European physicians' applications exceeded their professional and scientific duties became a political issue, and were on the agenda of European ministers and plenipotentiary ministers of England and France. Through the present article, the political and social applications of European physicians and their role in the political relationship of Iran with the European first grade powers in Nasseri period was studied.
\end{abstract}

Key Words: Iran, European Countries, Shah's private Physicians, Political Equations.

\footnotetext{
${ }^{1}$ Dr., University of Tabriz, Department of History. E-posta: Parghoo@tabrizu.ac.ir

${ }^{2}$ Dr., Researcher and Lecturer of Tabriz University. E-posta: abdollahi@tabrizu.ac.ir
} 


\section{1- Introduction}

Europeans were present in Asian and Eastern countries after the renaissance and the scientific revolution and the exploration of the marine ways. The European political, economic and religious panel stepped in eastern countries with a special goal. European countries were interested in Iran because of its strategic situation and neighborhood with Ottoman Empire. European's presence was increased especially from Shah Abbas I period, and people from Europeans were served as the counselor and ambassadors. Through the next periods, the traffic of Europeans to Iranian court was increased. In the war between Iran and Russia, the Qajars benefited from the European officers and gunner's services and did some reforms by their help in office system and organization. Over the time, the presence of Europeans increased in other fields like medicine. The Qajar Shahs hired Europeans as their private physician and used them in the harem. This affair become formal in Nasser al-Din Shah's reign and usually the post of the shah's private physician was given to a European.

The presence of European physicians in Qajar shah's court had some social and political impacts. This profession created social and political advantages for the European physicians and by passing the time it led to the political influence and a kind of penetration for them. These physicians went beyond their professional work and consulted the shah and intervened in social and political works.

By increasing the penetration and power of European physicians in Qajar's court, the European rival countries tried to select the shah's private physician from their country and used different tricks and tools in this way. By involvement of the representatives and embassies of European countries in the choice of court physician, this issue found new dimensions and went beyond the scientific and medical issue and changed to a political factor. The political and social applications of European physicians and their penetration in court and their help in colonial policies of their respective countries are the samples of historical realities of Iran. Through this research, it is explored and studied.

About European physicians in Iranian court, different papers have been written. But the role of European physicians in Iran's foreign politics in Nasseri Era and their political application in Qajar court has not been independently studied. The present article tries to fill up this gap.

\section{The historical experience of European physicians in Qajar court}

The Qajar era is noticeable in scenes of Europeans' penetrations. In this period, most Iranians could travel to European countries and most Europeans 
entered Iran as the tourists, businessmen, missionary, archaeologists and the political agents. Physicians were the other group of Europeans which were present in the Iranian society. Due to the demand that was for their services, the European physicians gained great influence. By attention to the competition among the European countries for accessing the political and economic penetration, the choice of Iran's shah's private physician was changed to these powers' competition scene. In the European countries the politicians considered the presence of European physicians as a pleasurable chance for developing their goals since the European physicians were present in many places like embassies, consulates and religious communities and had relationship with Iranians directly and indirectly. These physicians not only did their job but also engaged in political and religious advertisements. Regarding the position that court physicians had, they usually accessed the information which usual people were unable to access. For example, Dr. Feuvrier wrote in his memorandum: "I who was the private physician of his majesty Nasser Al-Din Shah and saw his daily life, saw some things which not only no passenger could access that information but also accessing to that information for whom live in Iran is difficult."

In modern age, along the social reforms, it seemed necessary to found a modern medical council in Iran. In 1851 Amir Kabir, the Prime Minister to Naser Al- Din Shah, established the first modern school in Persia, called Dar Al- Funun (School of skills, or polytechnics), for training professionals in different fields including medicine and pharmacy. Owing to the shortage of professors in these fields, they hired professors from western countries, mostly from Austria led by Dr. Jacob Edward Polak. Dr. Polak recorded the arrival of these professors in his logbook in 1851. Many other European teachers also were in Dar Al- Funun. For example Dr. Focckette taught pharmacology. Another one was Dr. Johan Louis Schlimmer ${ }^{4}$. Dr. Schlimmer and Dr. Albo, a German physician, wrote most of the available books and manuscripts for use as teaching materials. Dr. Schlimmer wrote on various medical subjects such as pharmacology, pathology, ophthalmology, internal medicine and pediatrics. In

\footnotetext{
${ }^{3}$ Feuvrier, 2006, Introduction

${ }^{4}$ Dr. Schlimmer was born in 1819 and graduated from the Medical School of Leiden in Holland. After coming to Iran in 1849, he was first sent to Talesh. Then, he worked in Rashat, Guilan Province, in the North of Iran, where he was engaged in the treatment of patients with leprosy for a few years. Then, in 1855, he became the vicegerent of Dr. Jacob. Dr. Schlimmer joined the teaching staff at Dar Al-Funun in 1855 and worked there until 1864. He was an efficient physician and a superb teacher. He also studied endemic diseases such as leprosy and cholera in Iran, and was responsible for the clinical training of medical students at the State Hospital which was founded in 1852. (Azizi, 2006: 83-84)
} 
1874, he published his famous book entitled "Terminologie MedicoPharmaceutique et Anthropologique Francaise-Persane". It had been functioned as a small dictionary of Persian equivalents for the common French medical terms. Later on, it had grown into a major pharmacopoeia. Thus he created much of the modern medical terminology used in Iran. Dr. Schlimmer also made a great effort to learn how Persian doctors treated their patients ${ }^{5}$. Edward Brown writes: "In the middle of the nineteenth century much was being done by such men as Dr. Polak, the Austrian, and Dr. Schlimmer, the Dutchman, who went out to Persia to organize the new Polytechnic and Military Colleges."

In 1868 the first National Sanitary Council (Majlis-i hifz al-sihha) assembled in Tehran. The Council was headed by Dr. Joseph Desiree Tholozan ${ }^{7}$. All the famous physicians of the capital and the foreign embassies attended the council ${ }^{8}$. Edward Brown such writes about the health council: "When I was at Tehran in 1887 Dr. Tholozon, physician to His late Majesty Nasiru'd-Din Shah, kindly enabled me to attend the meetings of the Majlis-iSihhat or Council of Public Health, in the Persian capital, and most of the physicians in attendance at that time knew no medicine but that of Avicenna." Dr. Tholozan renewed basic vaccination that Dr. Cloquet had started ${ }^{10}$.

Actually, the presence of European physicians in Iranian society of that period was so chromatic that usually Iranians considered the physician and European as the same and thought that all Europeans had medical knowledge. According to Flandon "In eastern view, all Europeans are physician." In his trip to Iran, Ojen (Eugene) Flandon met with the same scenery. A woman referred to him for curing and treating her sick child and in front of his abstains; he was faced with this answer: "you are European, so you are physician, you must treat and cure my child." ${ }^{11}$ Liard stated the similar scene from his tripe: "for resting our animals, we stopped in Lardkan Castle. When people knew that I am European, they surrounded me, because they thought each European is a physician." ${ }^{12}$.

\footnotetext{
${ }^{5}$ Azizi, 2006: 83-84.

${ }^{6}$ Brown,1921: 94.

${ }^{7}$ Afkhami: 210.

${ }^{8}$ Elgood,1977: 571.

${ }^{9}$ Brown, 1921: 93.

${ }^{10}$ Elgood,1977: 571.

${ }^{11}$ Flandon, 1978: 209.

${ }^{12}$ Ensafpour, 2009, 139-140.
} 
The presence of European physicians in Qajar court became common from Abbas Mirza period ${ }^{13}$. Abbas Mirza appointed English Kormik as his private physician. Mohammad Shah continued this procedure and hired French Labat and then Cloquet ${ }^{14}$ as his private physician ${ }^{15}$. Also Dr. James Riyak, from England, was Mohammad Shah special doctor. But he was fired with pressure of Russians in $1836^{16}$. Dr. Cloquet, the Shah's French physician, was son and nephew of the two famous surgeons of the same name ${ }^{17}$.

Since that time, European physicians were involved in political applications and missions which had been given by their governments. Also they tried to participate in Iranians national and religious celebrations and social events. So that, in Shah's soup-cooking ceremony which was held every year, the court's physicians were present: "Dr. Tholozan and Schneider ${ }^{18}$ also, Private physicians of Shah, filled up their bowel and drank it and praised the shah." ${ }^{19}$. In real, European physicians were valuable for European governments because of their relations with Qajar gentlemen and common people. So this aspect of European physicians' activities in Iran was praised and verified by European governments and politicians. Sir Denis Wright mentioned a physician named "Andrew Jakes" (Andrew Jukes) who was hired as the political representative, translator and surgeon in Iran and according to Wright he mixed up the medical with politics ${ }^{20}$. He mentioned "Mack Nile", the other England physician as a person who was completely hired in political goals of England in Iran: "nobody did recognize the profits of medical-political as the medium of secret relationships of embassy and shah better than Mack Nile."

This custom was kept in the next periods and the political organization of England and other European countries used the European physicians for

${ }^{13}$ Abbas Mirza had sent two Iranians for study in England: One of them was Mirza Haji Baba, who studied medicine and in later times became one of court physicians. Second person was Mirza Kazem, who was studying Painting and graphic and died from illness in London.

${ }^{14}$ Dr. Ernest Cloquet was Nasser Al-Din Shah's private physician. He got married to Soleiman Khan the Georgian's daughter who was Christian and had a son in the name of Mirza Yousef. He was one of Dar Al- Funun masters. Dr. Cloquet passed away in 1268 (A.H.) because of mistake which he made and drank poison instead of wine. (Ardakani, 1968:366).

${ }^{15}$ Lord Curzon, 1969:522

${ }^{16}$ Shell, 1989: 189

${ }^{17}$ Sheil, 1856: 145

${ }^{18}$ Dr. John Justin Aten Sneider was born in $24^{\text {th }}$ June 1854 in the suburbs of Metz in AlsaceLauren. He was the private physician of Mozaffar Al Din Mirza (the next Mozaffare Al-Din Shah) from October 1893 to July 1907. He came back France after 14 years' duty and retired in 1914 and passed away in 1917 because of a heart attack. (Ayati, 2005: 189-192).

${ }^{19}$ Moayyer Al- Mluk, 1983:75

${ }^{20}$ Wright, 1978: 118

${ }^{21}$ Wright, 1978, 120 
developing their political goals and plans. So that, the other English physician named "Hugh Adeock" who was at the service of prince Mozaffer Al-din Shah, after the enthronement of Mozaffer Al Din Shah, came to Tehran, and according to Denis Wright "He like Dixon and other physicians was the profitable secret medium for relationship between embassy and shah." ${ }^{22}$. It is interesting that European officials not only did not deny their penetration in Iran, but also considered it as the natural right for themselves. Sir Spring Rice, English minister plenipotentiary in Mozaffar Al-Din Shah and Mohammad Shah' court, recognized the continuity of England's penetration in Iran profitable for Iran and claimed that Iranians did not know that "If England's penetration in Asia be omitted or reduced, what disaster will be created for themselves and their country." ${ }^{23}$.

This question is arises that why Iran's court did use the European physicians service? It seems that this issue was originated from inactivity and old and abolished methods of Iranian physicians. Iranian physicians who were called Hakim did not been familiar with the new technologies and sciences, and did not try to get new knowledge and learn new medical sciences. This issue is recognized in lampoon that Nasser Al-din shah has said about Hakim AlMamalek:

"O, Hakim Al-Mamalek,

Whom Luqman must be your trainer

Whom Plato is your minimum slave

Aristotle is foolish compared with you

If you be the physician next year

Nobody will be alive in Iran territory

This great Plato

Probably is fondled by king's kindness" 24

In Nasser al-Din Shah's memorandum, he wrote some issues which shows his distrust to Iranian physicians and in contrast his trust and confidence to European physicians: "Hakim Tholozan and Malek Al-Soltan, Hakim AlMamalek and other physicians have gathered around regent (shah son) and try to cure him and do not listen to Tholozan." ${ }^{25}$. Lady Sheil writes that in Iran in Nasseri era rich and well to do Iranians all preferred European doctors to Iranian Hakims, because Iranian Hakims diagnosis were usually wrong, and

\footnotetext{
${ }^{22}$ Wright, 1978, 121.

${ }^{23}$ Rice, 1996:81.

${ }^{24}$ Nasser al-Din Shah, 2007, 155.

${ }^{25}$ Nasser al-Din Shah, 1999: 44.
} 
they used old medicine. She adds: "The dreadful practice of the Persian doctors is quite enough to drive the fair dames of Tehran to an English physician."26

Iranian physicians, instead of improving their knowledge, tried to ruin, destroy and disparage the European physicians. In "The adventures of Hajji Baba of Isfahan", Hakimbashi is the Iranian physician who is worried about European physician's penetration in court and attempts to defeat and disgrace him. Hakimbashi tells Hajji Baba, his trainer, "Hajji, you must know that an ambassador from the Franks is lately arrived at this court, in whose suite there is a doctor. This infidel has already acquired considerable reputation here. He treats his patient in a manner quite new to us, and has arrived with a chest full of medicines of which we do not even know the names. He pretends to the knowledge of a great many things of which we have never yet heard in Persia. He makes no distinction between hot and cold diseases, and hot and cold remedies, as Galenus and Avicen have ordained."27. In the other occasion, after treatment of shah by the pill of European physician, Iranian hakim tries to discredit European physician and says that its impact should be because of evil spirits. Since the spirits are the enemy of right and are the instrument in the hands of misbegotten, and one of them is in hand of this infidel who rejects our prophet and calls him a cheat and rejects the kismet ${ }^{28}$. As well as, Hakimbashi tries to scare Shah from European governments' domination. To deter him from referring to European physician, he claims that their purpose is seizure of the countries and desperation of kings and buildings, as it was seen in India. But about the European physician's cure and therapy case, he says "Heaven preserve your majesty from them! They are just as treacherous in their effects as the Franks are in their politics." ${ }^{29}$. Insofar, all Iranian physicians' tricks were ruined by the golden opportunities which courts' and specially the shah's illness gave to European physicians. For example, in Nasser al-Din Shah's illness in coming back from his third trip from Europe, Iranian physicians were unable to cure him. Because of their wrong perceptions, he was dying. In this case, they had to let Dr. Feuvrier to treat and cure the Shah. Dr. Feuvrier attracted the shah and court's trust, so that all people from shah to court did flattery out him, and he

\footnotetext{
${ }^{26}$ Lady Sheil such describes the method of Iranian hakims: "I am told they give the most nauseating draughts, in immense quantities, to their patients two or three quarts at a time. Then they divide all maladies into cold and hot, which are to be attacked by corresponding opposite medicines. Thus a hot disease is to be combated by a cold remedy. The classifications of these last are somewhat fanciful. Pepper, I know, is cold, and ice, I think, is "hot." It can hardly be otherwise than hot, for it is applied to the stomach in large pieces during cholera." (Sheil 1856: 213)

${ }^{27}$ Morier: 99).

${ }^{28}$ Morier, 1972:193-194

${ }^{29}$ Morier, 1972, 210
} 
was shocked: "the shah thanked me and exaggerated about curing. Amin Alsoltan promised to bestow his best horses which were in his stable; also, Majd Al-doleh promised to give a great carpet. Each person undertook the gift to his value. Even one of the ministers told they should have kissed the physician's hand. ${ }^{30}$

Insofar, the physician profession for Europeans in Iran was not easy. Because of damages which they had seen, Iranians viewed them with suspicion and did not trust them. Dr. Polak ${ }^{31}$ in his itinerary to Iran pointed out that: "Now, hate to Europeans is so high that we just by sacrifice and dedication can work and keep our head above the water."132. However, according to Polak, this job was so attractive that even some adventures and tricksters had been entered this profession and cured people: "One European who had a little information in pharmacy, by attaching himself to one of the embassies, had found the army physician post. When the Shah was informed about that, and stated that he did not know anything about medical, shah laughed and answered: "I know very well that he can't teach medical to anybody since it is done in school, but I don't know why I should not hire anybody whom I like." ${ }^{33}$. Ojen Flandon in his itinerary refers to a European physician, who according to him did not had any information about medical but was a good $\operatorname{man}^{34}$.

\section{3- Consultant and Teacher}

In Nasseri Era, French physicians surpassed their English and Austrian competitors. It can be said that Nasseri Era was the authority period of French physicians in Iran's court. The French tried to keep this score and did not let their competitors take this status from their hands. Because of political profits which the court physicians and shah's private physicians had for European

\footnotetext{
${ }^{30}$ Etemad Al- Saltaneh writes: "Dr. Feuvrier said that the situation of shah is serious, but the Iranian illiterate physicians, Sheykh Al- Attebba and Fakhr Al- Attebba, prevented him." (Etemad Al- Saltaneh, 1978: 188) (Feuvrier, 2006, 69).

${ }^{31-}$ Dr. Jacob Edward Polak was born in Bohemia. Dr. Polak was the member of panel whom was invited by Amir Kabir came to Iran for teaching in Dar Al- Funun in 1851. (Shamim, 2002: 165). At first, he worked as the physician and surgeon in Dar Al -Funun. Dr. Polak established the bases of modern medicine in Iran and started the teaching modern physician and surgery at Dar Al-Funun (Vaferi, 2006: 143; Dezfouli,2007: 81). In 1855, after Dr. Ernest Cloquet's death, he was selected as Shah's private physician. He lived nine years in Iran, learned the Persian language and was familiar with culture of Iran. Through these years he travelled to different parts of Iran and published his observations titled "Iran and Iranian". He passed away in 1891 in Vienna when he was 73. (Azizi, 2005: 151-152)

${ }^{32}$ Polak, 1982. 407

${ }^{33}$ Polak, 1982, 411

${ }^{34}$ Flandon, 1978:74
} 
countries, European governments spent a lot effort to select the shah's private physician of their own nationality. In real, the competition of England, France and Russia in Iran was brought to this field ${ }^{35}$. In the secret letter from political representative of France in Tehran to Paris in $18^{\text {th }}$ Feb. in 1895 (War ministry, Emergency Section, Hospital's Office) it was written that: "Our country should have a physician inside this country, who should be familiar with Iran's issues and favored by Shah. So, the prince's physician could access the shah's private physician's status. For keeping our country's profits, European staff minister emphasizes on this issue that another European physician should not be replaced instead of Dr. Tholozan." In continue, Dr. Schneider was suggested as the suitable option ${ }^{36}$. In the other letter which was sent in $19^{\text {th }}$ April 1906 from France European staff to charge affaires in Tehran, it was stated that: "We have been informed by the Russian ambassador in Paris that an English physician will be replaced instead of Schneider as the hospital's Presidency of the Council of Iran. These applications will be unfortunate. I guess that you are trying to prevent its application." 37 . In the letter which was written from French embassy in Tehran to French European staff in $18^{\text {th }}$ March 1899, had been stated that the presence of Schneider in Iran's court and since "his new duties let him to enter the court freely" was the source of happiness ${ }^{38}$. Dr. Schneider himself through the letter which was written to French War Ministry by himself in $20^{\text {th }}$ September 1904, mentioned his successes in duty fields as this: "I am so satisfied about all successes that I had, since these tasks cause to do my missionary which French government has given me in 1893 perfectly. As in the past, I will try to keep the influence of France in Iran, especially after the exceptional condition which is accessed for me." ${ }^{39}$.

European physicians in addition to treatment and curing involved in cultural tasks: Austrian Dr. Polak taught French language, history and geography to Nasser Al- Din Shah ${ }^{40}$. Also, by his encouraging, Iranian officials dispatched some talented young people and Dar Al-Funun's graduates to Paris to study medicine. Many of these people later won important place in modern medical of Iran. Moreover, Polak introduced the sugar beet to Iranians, and it is said that he was the first person who brought the beet seed to Iran ${ }^{41}$. Polak also concentrated on the Persian craft and industry traditions. He had some

\footnotetext{
${ }^{35}$ Mohammadi, 2009, 5

${ }^{36}$ Ayati, 2005, 193

37 Ayati, 2005, 202

38 Ayati, 2005, 197

39 Ayati, 2005, 200

${ }^{40}$ Gashtar, 2007, 191

${ }^{41}$ Gashtar, 2007, 189
} 
comments on Iranian crafts, for example, he comments on backwardness in ministry skill and capability in using machines from Europe ${ }^{42}$. After returning to Austria, he was engaged in Iran's issues and consulted with his countries authorities and played important role in the negotiations between Austria and $\operatorname{Iran}^{43}$. Dr. Tholozan read the European newspapers' news at lunch to Shah and informed him of the events ${ }^{44}$.

Due to his medical and non-medical knowledge, Dr. Tholozan ${ }^{45}$ had acquired the best status in Iran and among the court and shah himself. He not only was the private physician of shah and his harem but also was his consultant and teacher. Tholozan was with shah everywhere and according to Malijak: "Dr. Tholozan the head of physicians whose status was recognized, always was with shah and traveled with him." ${ }^{46}$. A Russian traveler that had been in Iran at that time has written that Dr. Tholozan was closer to shah than even princes and ministers ${ }^{47}$. His closeness to shah caused to raise some people's envy. So that, Eatamad Al- Saltaneh criticized the destructive role of Tholozan in Iran. Especially, after the death of Eatamad Al- Saltaneh's daughter and Dr. Tholozan failure to cure her: "damn of seventy generations after Tholozan who is one of the destructors of Iran's government. Moreover, he has betrayed the medicine sect. He is old and foolish and cannot work and because of jealousy, he doesn't let other physicians be at service of shah." ${ }^{48}$. Unlike Eatamad Al- Saltane, Haj Sayyah (Traveler) has mentioned Dr. Tholozan in his memorandum with praise, because of his benevolence. According to Haj Sayyah, Tholozan is closest person to shah and earns 40,000 Tomans (Iranian currency), he spends, however, more than it for poor people and he is not jealous of anybody. He has only a fault that he is not Muslim. (Haj Sayyah, 1978: 01). Ernest Orcell in his itinerary has written some things about Dr. Tholozan that verifies Haj Sayyah: "Lalehzar Street is also named after Dr. Tholozan, since "Head of Physicians" has settled in this street. Of course, it is not a palace, but it is a simple privacy

\footnotetext{
${ }^{42}$ Avery, 2008: 940

${ }^{43}$ Geshtar, 2007, 191

${ }^{44}$ Mokhber Al- Saltaneh, 2006, 96.

${ }^{45}$ - Dr. Joseph Désiré Tholozan was born in 1820 in Diego Garcia in Gags Island. Before coming to Iran, he was the physician of the France Military. He was the private physician of Nasser AlDin Shah for long time. In Shah's last trip to France, he stayed in France and send Dr. Yohan Feuvrier instead of himself, but after a while he came to Iran and was present in Shah's being shot. Tholozan passed away in 1897 in Tehran when he was 77 and was buried in the Catholic cemetery in Akbar Abad Dulab. (Behzadi, 2009:1112). Tholozan was the first one who introduced Mianeh's famous bugs to medical world.

${ }^{46}$ Afrasiabi, 1989:187

${ }^{47}$ Nasiri, 1984: 48

${ }^{48}$ Etamad Al- Saltaneh, 2006, 954
} 
home where is suitable for a physician like him. The door of his home is open both for famous peoples and helpless residents." ${ }^{49}$. Madam Dieulafoy in her itinerary wrote: "Dr. Tholozan in addition that is shah's physician is his consultant because of his vast knowledge and is respected by shah",50. Ernest Orcell called Dr. Tholozan as the "Shah's trusted consultant" 51 . In Tobacco Protest when Nasser al-Din faced with some problem in supplying the considered compensation, he consulted with Dr. Tholozan. Dr. suggested that an international company be formed to supply the required amount. By this way, Dr. Tholozan hoped to persuade the English and French investors to access this job, but none of them showed tendency ${ }^{52}$.

Dr. Feuvrier was another court physician. He entered the political and economic issues and met with Iran's gentlemen: "Because of long familiarity Etamad Al-Saltaneh spoke to me freely about government issues. Today, after the dinner, he spoke completely to me about the rating of bank and alcoholic drinks." ${ }^{33}$. Although his influence in Iran's court was not comparable to Dr. Tholozan, and his name was mentioned less in Iran economy and political issues, his influence in shah and court was great. He has been cited as one of the counselors of shah and utilized this influence for benefit of himself and his country. Dr. Feuvrier's records in his itinerary indicate and verify this issue. Dr. Feuvrier praises shah and writes: "Nasser Al-Din Shah with induction of European physicians, like his French physician, has adapted a manner in contrast to the old fashion. This change shows his intellectuality and that he admits the advantage of European custom and wants to imitate it and he wants to omit the superstition among the people." ${ }^{54}$.

\section{4- Political and Economic activity}

As it was mentioned, due to their influence the European physicians entered in different fields and used their influence in court and society. As an example, the activities of Dr. Tholozan can be mentioned. Dr. Tholozan took the ranting of Ahwaz dam from shah, although as Amin Al- Dowleh wrote he did not benefit from that privilege and was not implemented ${ }^{55}$. But this application and his insist for taking that shows his involment in affaires which were not related to his task. In Etemad Al- Saltaneh memories, Dr. Tholozan's

\footnotetext{
${ }^{49}$ Orcell, 1974: 111

${ }^{50}$ Dieulafoy, 2011, 139

${ }^{51}$ Orcell, 1974:111

${ }^{52}$ Kazemzadeh, 1974, 250

${ }^{53}$ Feuvrier, 2006, 82

${ }^{54}$ Feuvrier, 2006, 147

${ }^{55}$ Amin Al- Dowleh, 1991, 159
} 
economic activities have been noted in brief: "I went to Ala E-Doleh's home. Dr. was there. They had written their ideas about building some factories in Iran on a paper." ${ }^{56}$. On the other occasion, Etemad Al- Saltaneh, pointed out the ranting of Ahwaz dam and said: "I went to Tholozan's home, but he was not happy. Through the conversation I found out that there had been a curbing in fulfilling his purpose in achieving the ranting Ahwaz dam." ${ }^{57}$. In Nasser Al- Din shah's travel to Europe, "Dr. Tholozan" could get the ranting of mines, watering and railways by using his influence. In the draft of the ranting, it was mentioned that: "The Iranian government grants the company to establish factories and etc.". But the rant of Tholozan was met with strong opposition of the English and he didn't get anything. In failure of Ahwaz dam, the English played an important role. After the cancellation of Router Ranting, the English were not satisfied that a ranting to be given to their French competitors in Iran. Taylor Thompson wrote: "By attention to the importance of preventing the formation of a French society (or any society affiliated to other European countries) in Khuzestan state, which may be in contrast with Britain benefits in that territory, it is suggested that until Baron Reuter has not suggested new offers to government of Iran, it is better not to accept Dr. Tholozan's plan". By the pressure of the English the Iranian government had to retreat and for one year there was no speech of Tholozan Rant. In spring of 1878, during the shah's stay in Paris, this issue was mentioned again and a new draft was prepared. On return to Tehran, Tholozan and his friends tried to finish the case, but they failed. After concealing the rant which had been given to Tholozan, Thompson who had tried to ruin Dr. Tholozan's rant, wrote: "His Majesty asked me to tell Lord Salisbury that this decision was done because of some notes which I sent to Iran and caused government to attend more about Tholozan's plan's contestable identity." 58

Dr. Tholozan was consulted by French officials due his knowledge of Iranian issues. For example, he had influence in the choice of French ambassadors in Iran. So that he played important role in selecting Monsieur Triko as the minister plenipotentiary in Iran. Since Tholozan always and strictly criticized the Monsieur because of his frailty and lethargy, and believed that Iran needs a stronger person ${ }^{59}$.

\footnotetext{
${ }^{56}$ Etemad Al- Saltaneh, 2006, 26

${ }^{57}$ Etemad Al- Saltaneh, 2006, 804

${ }^{58}$ Kazemzadeh, 1974:143-145

${ }^{59}$ Key, 1974: 183
} 


\section{Conclusion}

The presence of European physicians in Iran was in pursuit of Westerner's interest in East. The adventure and curiosity of physicians and the need for their services were the reason of their presence in Iran.

Although European physicians were at service of colonial policies and shared in strengthening the European powers' domination, they did some services for Iran and caused to transfer the latest medical knowledge to Iran. Some of these physicians went beyond their duties and did some other services to Iran. Their lengthy resident in Iran caused their interest in Iran's culture and history. People like Dr. Tholozan involved in public works and helped to Iranian poor and helpless.

Insofar, in conclusion, and regardless of their personal intent and their love to Iran, there is no doubt that these physicians were at service of their respected countries and used their special status for this purpose. European countries' sensitivity about choose of shah's private physician and their strict competition is only feasible in this frame. 


\section{BIBLIOGRAPHY}

Afkhami, A. Disease and Water Supply: The case of Cholera in $19^{\text {th }}$ Century Iran. Middle Eastern Natural Environments (environment.yale.edu/publication-series/.../0-

9/103afkhami.pdf- 2016/3/15)

Afrasyabi, B. $1989 \quad$ King Zol Gharnain and Malijak's Memories. Tehran: Sokhan.

Amin Al-Dowleh 1991 The Political Diary of Amin Al-Dowleh, with Efforts of Hafez Farmanfarmaian. Tehran: Amirkabir.

Ardakani, H. 1968. “Dr. Cloquet”, Yagma, No. 241, pp. 364-368.

Ayati, A. 2005. Secret Proofs of Mozaffar Al- Din Shah's Illnesses. Iran Contemporary History, Iran. No. 34, pp.185-230.

Azizi, Mohammad-Hossien 2005

"Dr. Jacob Eduard Polak (1818-1891): The Pioneer of Modern Medicine in Iran", Archives of Iranian Medicine, Volume 8, pp.151-152.

Azizi, M. 2006 "Dr. Johan Louis Schlimmer (1819-1881): The Eminent Professor of Modern Medicine At Dar Al- Funun School", Archives of Iranian Medicine, Volume 9, Number 1, pp.83-84.

Behzadi, M. 2009 "The Dissertation of Dr. Tholozan The Hakim Bashi of Nasser Al-Din Shah-h Qajar", Payame Baharestan. Year 2, Number 6, pp.1136-1221.

Brown, E. $1921 \quad$ Arabian Medicine. London: Cambridge University Press.

Dezfouli, A. 2007 "History of Thoracic Surgery in Iran", National Research Institute of Tuberculosis and Lung Disease, 6(2), pp.80-91.

Dieulafoy, J. 2011 Madam Dieulafoy 's Itinerary "Iran and Keldeh". Translated by Farah Vashi (Former Homayoun). Tehran: Donyay-e- Ketab.

Elgood, C. 1977 A Medical History of Persia and The Eastern Caliphate. Translated By, Baher Forqani. Tehran:Amirkabir.

Ensafpour,M. 2009 "Thesis for Dr. Tholozan the head physician of Nasser Al- Din Shah", Payam Baharestan, $2^{\text {nd }}$ period, $2^{\text {nd }}$ year, No. 6. Winter, pp.1121-1136.

Etemad Al-Saltaneh 1978

Khalseh Mashour Be Khabnameh. Tehran: Tooka.

Etemad Al-Saltaneh 2006

Etemad Al-Saltaneh's Memorandum Newspaper. Tehran: Amirkabir.

Feuvrier, Y. 2006 Three Years in Iran's Court. Translated by, Abbas Eghbal.Tehran: Nashr-e- Ghalam

Flandon, O. 1978 Flandon's Itinerary to Iran. Translated by, Hossein Nour Sadeghi. Tehran: Eshraghi Publication. 
Gashtar (Jalilzadeh), A. 2007

"The history of transferring knowledge between Iran and Austria: Yasemen Thaghafi", Bokhara, No. 64. December and March, pp.184-194.

Haj Sayyah 1978 Haj Sayyah's Itinerary, tried by Hamid Sayyah. Tehran: AmirKabir.

Kazemzade, F. 1974 Russia and England in Iran 1864-1914, a research about Imperialism. Translated by, Manuchehr Amiri. Tehran: Pocket Books Co.

Key, M., 1974 "The Letters of Iran's Minister Plenipotentiary in France”, The Historical Explores, No. 3, tenth year, pp. 169-196.

Lord, C. and Gorge, N. 1969

Iran and Iran's issue. Translated by, G. Vahid Mazandarani. Tehran: Translating and distributing the book Institution.

Morier, J. $1972 \quad$ Stories of Hajji Baba of Esfahan in Iran. Translated by Mirza Habib Esfahani, Juseph Rahimlu. Tabriz: Haj Mohammad Bagher Ketabchi bookstore.

Morier, J. The Adventures of Hajji Baba of Ispahan. London: The Cresset Press.

Moayerro Al-mamalek, Doost Ali Khan 1983

Notes of Shah's Private Life. Tehran: Nashr-e Tarikh-e Iran.

Mohammdi, Z. and Mohammdi, G. 2009

"Rooting the reasons of England physicians' presence in Qajar Era and their role in political, social, religious and science issue of that time", European Relationships' History. No. 38 and 39. Spring and Summer, pp.1-22.

Mokhber Al-Saltaneh 2006

Haj Mehdi-Gholi Hedayat, Memories and Dangerousness. Tehran: Zavvar.

Nasiri, M. 18 Iran Report 1887 from a Russian Traveler. Translation by Seyyed Abdollah. Tehran: Tahuri Lab.

Nasser Al- Din Shah 2007

Nasser Al- Din Shah's Complete Poems. Qom: Tahzib.

Nasser Al-Din Shah 1999

Nasser Al-Din Shah's Daily Notes (1300 -1303 AH), Smith Novel. Tehran: The National Archives of Iran.

Orcell, E. $1974 \quad$ Orcell's itinerary in 1882. Translated by Ali Asgar Saeidi. Tehran.

Polak, Y. 1982 Polak's itinerary "Iran and Iranian". Translated by Keikavus Jahandari. Tehran: Kharazmi. 
Rice, S. 1996

The personal Letters of Rice in Iran. (In Mozaffar Al- Din Shah's period). Translated by Javad Sheikh Al - Islami. Tehran: Ettelaat Publication.

Sheil, Lady M. 1856 Glimpses of Life and Manners in Persia. London: William Clowes and Sons.

Vaferi, L. Vaferi, H. and Vaferi, R. (2006).

"The history of developing the traditional Medical to Novice Medical in Qajar Era", Alzahra University's Humanistic Sciences Research-scientific Journal, Year 16, pp. 131-165.

Avery, P. 2008 The Cambridge History of Iran, Volume 7, Cambridge: Cambridge University press.

Wright, D. 1978 The English in Iran. Translated by Gholam-Hosein Sadri Afshar. Tehran: Donya. 